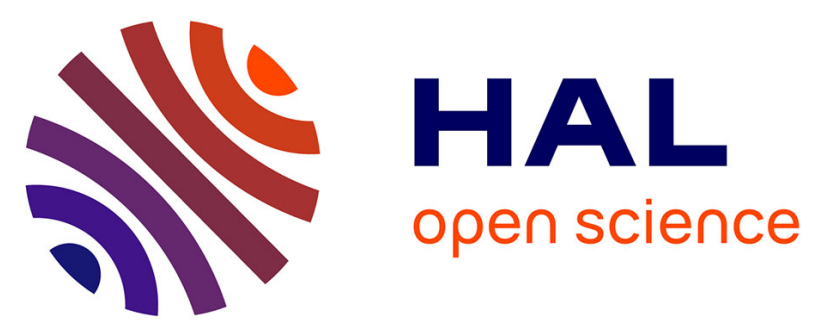

\title{
An oceanic subduction origin for Archaean granitoids revealed by silicon isotopes
}

Zhengbin Deng, Marc Chaussidon, Martin Guitreau, Igor Puchtel, Nicolas Dauphas, Frederic Moynier

\section{- To cite this version:}

Zhengbin Deng, Marc Chaussidon, Martin Guitreau, Igor Puchtel, Nicolas Dauphas, et al.. An oceanic subduction origin for Archaean granitoids revealed by silicon isotopes. Nature Geoscience, 2019, 12 (9), pp.774-778. 10.1038/s41561-019-0407-6 . hal-02278676

\section{HAL Id: hal-02278676 \\ https://hal.uca.fr/hal-02278676}

Submitted on 3 Sep 2021

HAL is a multi-disciplinary open access archive for the deposit and dissemination of scientific research documents, whether they are published or not. The documents may come from teaching and research institutions in France or abroad, or from public or private research centers.
L'archive ouverte pluridisciplinaire HAL, est destinée au dépôt et à la diffusion de documents scientifiques de niveau recherche, publiés ou non, émanant des établissements d'enseignement et de recherche français ou étrangers, des laboratoires publics ou privés. 


\title{
An oceanic subduction origin for Archaean granitoids revealed by silicon isotopes
}

\author{
Zhengbin Deng ${ }^{1 \star}{ }^{1 \star}$, Marc Chaussidon', Martin Guitreau $\mathbb{1}^{2}$, Igor S. Puchtel ${ }^{3}$, Nicolas Dauphas $\mathbb{D}^{4}$ and \\ Frédéric Moynier ${ }^{1,5}$
}

\begin{abstract}
Modern oceanic crust is constantly produced at oceanic ridges and recycled back into the mantle at subduction zones via plate tectonics. An outstanding question in geology is whether the Earth started in a non-plate tectonic regime, and if it did, when the transition to the modern regime occurred. This is a complicated question to address because Archaean rocks lack modern equivalents to anchor interpretations. Here, we present a silicon isotopic study of 4.0-2.8-Gyr-old tonalite-trondhjemitegranodiorites, as well as Palaeozoic granites and modern adakites. We show that Archaean granitoids have heavier silicon isotopic compositions than granites and adakites, regardless of melting pressure. This is best explained if Archaean granitoids were formed by melting of subducted basaltic crust enriched in sedimentary silica through interaction with seawater. Before the appearance of silica-forming organisms 0.5-0.6 billion years ago, the oceans were close to silicon saturation, which led to extensive precipitation of cherts on the seafloor. This is in contrast to modern oceans, where silica biomineralization maintains dissolved silicon at low concentration. The unique heavy silicon isotope signature of cherts has been transferred to Archaean granitoids during an oceanic subduction process, which was probably responsible for the formation of felsic rocks on Archaean emerged lands.
\end{abstract}

M odern subduction-zone lavas are derived primarily from melting of the mantle wedge that is fluxed with fluids from the subducting plate. Except for rare rock occurrences known as adakites that are found at some subduction zones with a high thermal gradient of $\sim 40{ }^{\circ} \mathrm{Ckbar}^{-1}$ (ref. ${ }^{1}$; Fig. 1), modern subducting oceanic crust experiences only dehydration rather than melting because thermal gradients along the Benioff zone are too low on average $^{2}\left(\sim 25^{\circ} \mathrm{Ckbar}^{-1}\right)$. A remarkable feature of Archaean cratons is the prevalence of the tonalite-trondhjemite-granodiorite (TTG) suite (granitoids with high $\mathrm{Na}_{2} \mathrm{O} / \mathrm{K}_{2} \mathrm{O}$ ratios), which are thought to have been formed by partial melting of hydrated mafic crust at great depths $^{3}(>50 \mathrm{~km})$. However, the exact tectonic setting of this melting regime and whether it is indicative of subduction-driven magmatism in the Archaean are hotly debated ${ }^{4-10}$. Several authors have proposed a subduction-like setting, with thermal gradients between $\sim 40$ and $100^{\circ} \mathrm{Ckbar}^{-1}$ (refs. ${ }^{1,3,8,9}$ ) (Fig. 1), whereas others have suggested a stagnant-lid environment, such as partial melting at the base of thickened oceanic plateaus ${ }^{6,710}$. A telltale signature of Archaean oceanic crust would be its extensive interaction with seawater, which, if TTGs have been produced by melting of subducted oceanic crust, could have left an imprint on their chemical and Si and/or $\mathrm{O}$ isotopic compositions. A recent study ${ }^{11}$ suggested that combined analyses of $\mathrm{O}$ and $\mathrm{Si}$ isotopes could help unravel the contributions of different sedimentary components, such as hydrothermal silica, pelites and cherts, to the magmas from which Hadean and Archaean zircons crystallized. In this study, we show that $\mathrm{Si}$ isotope data can be used to directly trace the origin of Archaean TTGs.

Elevated Si isotopic ratios in TTGs

We report the $\mathrm{Si}$ isotopic compositions as $\delta^{30} \mathrm{Si}$ values (that is, the per mil deviation of the ${ }^{30} \mathrm{Si} /{ }^{28} \mathrm{Si}$ ratio in a sample from that of the NBS28 standard) of 3.50-2.70-Gyr-old komatiites (bulk rock samples), 3.98-2.79-Gyr-old TTGs (quartz separates and bulkrock samples) and a set of quartz separate samples from Palaeozoic granites previously studied for their bulk-rock Si isotopic compositions $^{12}$ (Supplementary Dataset 1). The komatiites (that are, ultramafic volcanic rocks interpreted as mantle-derived high-degree melts ${ }^{13}$ ) have an average $\delta^{30} \mathrm{Si}$ value of $-0.29 \pm 0.02 \%$ o (95\% confidence interval (95\% CI hereafter unless stated otherwise); $n=11$ ), which is identical to the modern bulk silicate Earth value estimated from modern mantle-derived rocks $\left(\delta^{30} \mathrm{Si}=-0.29 \pm 0.01 \%\right.$; $\left.n=64\right)$ (Fig. 1 and Supplementary Dataset 2). Bulk-rock TTG samples have an average $\delta^{30} \mathrm{Si}$ value of $-0.01 \pm 0.02 \%, n=14$, which is significantly higher than an average for bulk rock I- and A-type granites $^{12}\left(\delta^{30} \mathrm{Si}=-0.18 \pm 0.02 \%, n=19\right)$, but only slightly higher than that for modern adakites $\left(\delta^{30} \mathrm{Si}=-0.06 \pm 0.02 \%, n=4\right.$; Fig. 1 and Supplementary Dataset 2). The $\delta^{30} \mathrm{Si}$ values of bulk-rock TTGs are consistent with other reported data for TTGs from the Kaapvaal Craton that have $\delta^{30} \mathrm{Si}=-0.02 \pm 0.02 \%$ o $\left(n=37\right.$; ref. $\left.{ }^{14}\right)$. The difference in $\delta^{30}$ Si value between the quartz and bulk-rock samples of TTGs is similar to that measured between the quartz and bulk rock samples in I- and A-type granites (Supplementary Fig. 1 and Supplementary Text). This observation provides evidence that quartz from TTGs is at $\mathrm{Si}$ isotopic equilibrium with other coexisting minerals, and that the elevated $\delta^{30} \mathrm{Si}$ values in bulk TTGs reflect the composition of their parental magmas, rather than late contamination of the silicate melts by sedimentary components isotopically heavy in $\mathrm{Si}$. In the following section, we show that some of the variations in the $\delta^{30} \mathrm{Si}$ values of granites, TTGs and adakites can be accounted for by isotopic fractionation during partial melting, but that for the same pressuretemperature conditions of partial melting, TTGs have systematically higher $\delta^{30}$ Si values than Phanerozoic granites and adakites (Fig. 2).

'Université de Paris, Institut de Physique du Globe de Paris, CNRS, Paris, France. ²Université Clermont Auvergne, Laboratoire Magmas et Volcans, IRD, CNRS, UMR 6524, Aubière, France. ${ }^{3}$ Department of Geology, University of Maryland, College Park, MD, USA. ${ }^{4}$ Origins Laboratory, Department of the Geophysical Sciences and Enrico Fermi Institute, The University of Chicago, Chicago, IL, USA. Institut Universitaire de France, Paris, France. *e-mail: deng@ipgp.fr 


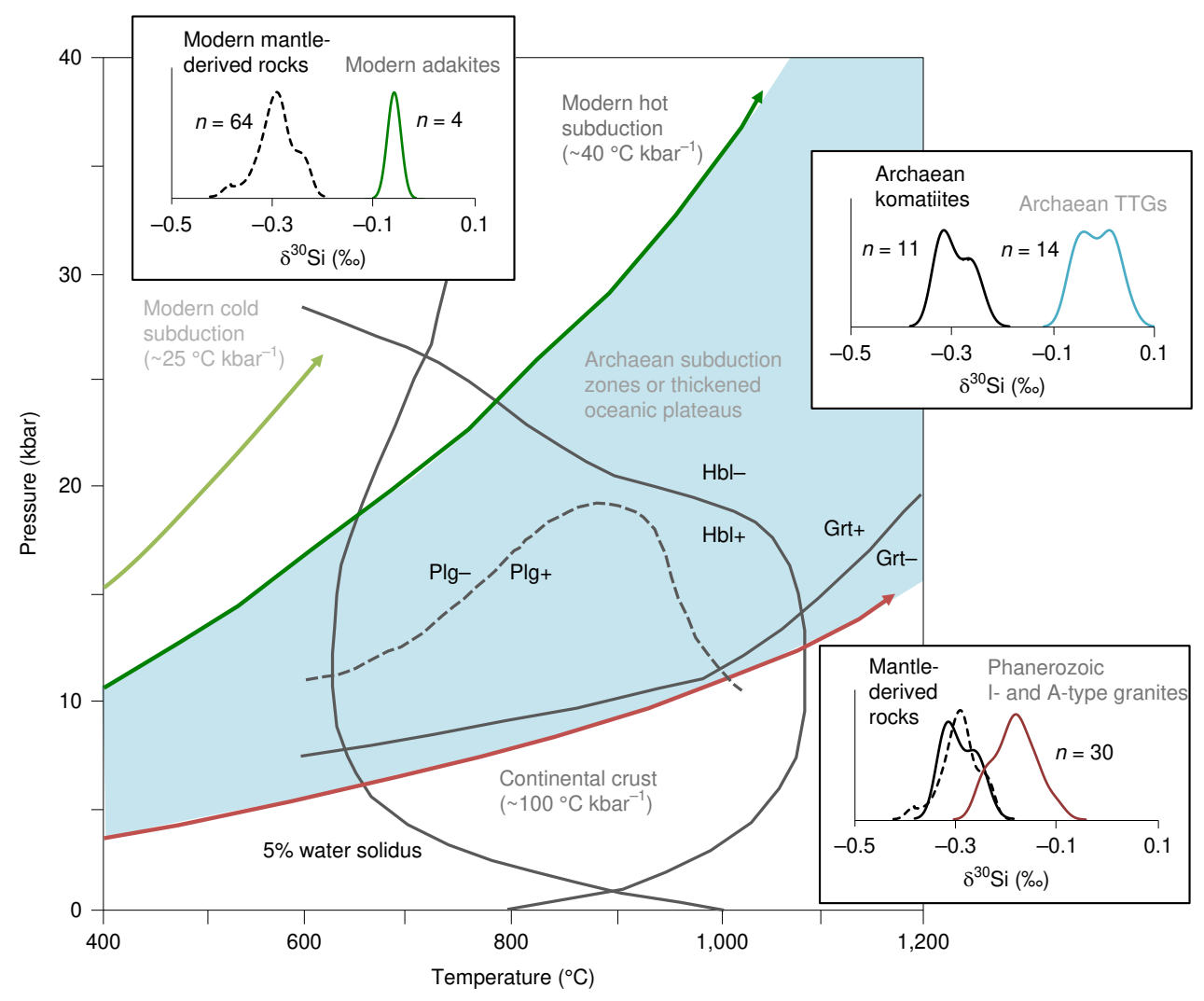

Fig. 1 | Pressure-temperature diagram and Si isotopic results. Phase equilibria relations for partial melting of a hydrous tholeiitic basalt under the thermal gradients of various geological settings ${ }^{1,2,7,10}$, taken from ref. ${ }^{1}$. The stability curve for plagioclase (black dashed curve) was not quantitatively constrained in ref. ', so the one calculated from the $\mathrm{H}_{2} \mathrm{O}$-saturated solidus at $12 \mathrm{kbar}$ from ref. ${ }^{10}$ is shown instead. $\mathrm{Si}$ isotopic data for Archaean TTGs and komatiites, Phanerozoic I- and A-type granites, and modern basalts, peridotites and adakites are shown as insets (from this study (Supplementary Dataset 1) and the literature (as compiled in Supplementary Dataset 2)). In the bottom-right inset, Si isotopic data for mantle-derived rocks, including the modern (black dashed curve) and Archaean (black solid curve) ones, are compared with those of Phanerozoic granites. Note that the decomposition of hornblende would release water and leave behind a dry refractory residue. Plg, plagioclase; $\mathrm{Hbl}$, hornblende; Grt, garnet.

\section{Quantifying the effects of melt-crystal segregation}

Silicon isotopic variations in igneous rocks are controlled by crystal-melt equilibrium fractionation during either partial melting or fractional crystallization processes ${ }^{12}$ (see details in Supplementary Text). First-principles calculations show that, at equilibrium, tectosilicates (for example, quartz and feldspar) have higher $\delta^{30} \mathrm{Si}$ values compared with nesosilicates (for example, olivine) and inosilicates (for example, pyroxene) ${ }^{15,16}$. The situation is not as clear for melts, but one can reasonably estimate the $\mathrm{Si}$ isotopic fractionation factors between minerals and silicate melts by considering the melt normative mineral compositions ${ }^{16,17}$ (for example, predominance of neso- and inosilicates in basaltic melts, and predominance of tectosilicates in felsic melts; Supplementary Dataset 5 and Supplementary Information), which has been shown to be a good approximation for $\mathrm{O}$ isotopes ${ }^{18}$. Future experimental and theoretical work will be needed to assess the validity of this approach for $\mathrm{Si}$ isotopic fractionation involving silicate melts, which is beyond the scope of the present study. Under the temperatures relevant to mantle partial melting $\left(\geq 1,400^{\circ} \mathrm{C}\right), \mathrm{Si}$ isotopic fractionation between olivine/pyroxene and basaltic melt is limited, and, at equilibrium, basaltic melts should have $\delta^{30} \mathrm{Si}$ values shifted by less than $0.04 \%$ \% relative to their mantle sources, as corroborated by the isotopic similarity between peridotites and mid-ocean ridge basalts ${ }^{19-21}$, as well as most oceanic island basalts ${ }^{22}$. During crustal magma differentiation, however, $\mathrm{Si}$ isotopic fractionation between melt and clinopyroxene/orthopyroxene/hornblende/garnet can be significantly enhanced due to the lower temperatures involved and stronger contrast in Si polymerization between the melt and the residual minerals ${ }^{17,23}$. At $850-900^{\circ} \mathrm{C}$ (typical liquidus temperatures for TTGs, I- and A-type granites, and $\mathrm{SiO}_{2}$-rich adakites), $\mathrm{Si}$ isotopic fractionation between felsic melt on the one hand, and pyroxene, garnet, and hornblende on the other hand, is $\Delta^{30} \mathrm{Si}_{\text {melt-cpx/opx/hb/grt }} \approx$ $+0.30 \%$, while the isotopic fractionation between granodioritic melt and plagioclase is only $\Delta^{30} \mathrm{Si}_{\text {melt-plg }} \approx+0.03 \%$ (ref. ${ }^{16}$; Supplementary Dataset 5). During crustal anatexis, the stability of plagioclase in the source is sensitive to the partial melting pressure $^{1,10,24}$ (Fig. 1). Therefore, melting of the crust under various thermal gradients should produce melts of varying Si isotopic compositions (Fig. 2).

Mineral assemblages in magma sources, including major (plagioclase, clinopyroxene, orthopyroxene, hornblende and garnet) and accessory (for example, ilmenite, titanite and rutile) phases, during partial melting of a basaltic protolith are intimately related to the pressure-temperature- $\mathrm{H}_{2} \mathrm{O}$ conditions of melting ${ }^{7,24}$ (see details in Supplementary Information). In the discussion below, we assume water saturation, but our conclusions do not rely heavily on this assumption, as $\mathrm{Si}$ isotopic fractionation during melting of the crust is mostly sensitive to the presence of plagioclase in the source, which we trace directly using the $\mathrm{Sr} / \mathrm{Sr}^{*}$ anomaly, that is, $\mathrm{Sr} / \mathrm{Sr}^{*}=\mathrm{Sr}_{\mathrm{N}} / \sqrt{\mathrm{Ce}_{\mathrm{N}} \times \mathrm{Nd}_{\mathrm{N}}}$ (subscript ' $\mathrm{N}$ ' represents a normalization to the bulk-silicate Earth values ${ }^{25}$; Fig. 2).

(1) Under a thermal gradient of $40^{\circ} \mathrm{Ckbar}^{-1}\left(\sim 13^{\circ} \mathrm{Ckm}^{-1}\right)$, partial melting of tholeiitic basalt takes place at pressures $>20 \mathrm{kbar}$ in 

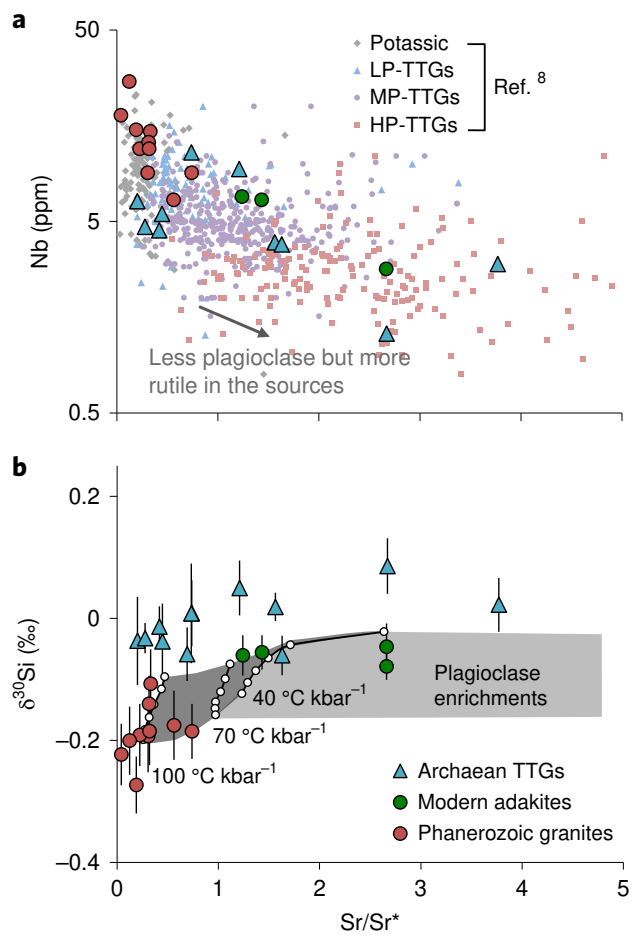

Fig. 2 | Trace-element and Si isotopic compositions. a, Nb concentrations and $\mathrm{Sr} / \mathrm{Sr}^{\star}\left(\mathrm{Sr} / \mathrm{Sr}^{\star}=\mathrm{Sr}_{\mathrm{N}} / \sqrt{\mathrm{Ce}_{\mathrm{N}} \times \mathrm{Nd}_{\mathrm{N}}}\right)$ values of Archaean TTGs, Phanerozoic granites and modern adakites (subscript ' $\mathrm{N}$ ' represents normalization to the primitive mantle values $\left.{ }^{25}\right)$. Archaean granitoids from ref. ${ }^{8}$ are shown as potassic, low-pressure (LP) TTG, medium-pressure (MP) TTG and high-pressure (HP) TTG groups. b, $\delta^{30} \mathrm{Si}$ and $\mathrm{Sr} / \mathrm{Sr}^{\star}$ values of studied samples. Partial melts of $5-30 \%$ ( $5 \%$ increments by batch melting models) under thermal gradients of 40,70 and $100^{\circ} \mathrm{C} \mathrm{kbar}^{-1}$ are represented by circles, which trend towards lower $\delta^{30} \mathrm{Si}$ and $\mathrm{Sr} / \mathrm{Sr}^{\star}$ values with increasing melting degrees. The dark grey area delineates the $\delta^{30} \mathrm{Si}$ and $\mathrm{Sr} / \mathrm{Sr}^{\star}$ range by partial melting, with the light grey field indicating the effects from plagioclase xenocrysts, which increase $\mathrm{Sr} / \mathrm{Sr}^{*}$ values in bulk without significantly changing $\delta^{30} \mathrm{Si}$ values. Uncertainties on $\delta^{30} \mathrm{Si}$ are shown at the $95 \% \mathrm{Cl}$.

the presence of residual garnet, clinopyroxene, hornblende and rutile $^{24}$. The absence of plagioclase means that $\mathrm{Sr}$ and $\mathrm{Eu}$ are incompatible, while garnet preferentially incorporates $\mathrm{Y}$ and $\mathrm{Yb}$, and rutile sequesters $\mathrm{Nb}$ and $\mathrm{Ta}$. The felsic melts generated under such conditions have low concentrations of $\mathrm{Y}, \mathrm{Yb}$, $\mathrm{Nb}$ and $\mathrm{Ta}$, and positive $\mathrm{Sr}$ anomalies, as typically observed in modern adakites that are considered to be partial melts from young and hot subducted oceanic crust ${ }^{26,27}$ (Fig. 2, Supplementary Fig. 2 and Supplementary Dataset 3). Th s plagioclase-free residue has a $\Delta^{30} \mathrm{Si}_{\text {melt-residue }} \approx+0.30 \%$ at $850-900^{\circ} \mathrm{C}$, and, therefore, a basaltic source with $\mathrm{SiO}_{2}=50 \mathrm{wt} \%$ and $\delta^{30} \mathrm{Si}=-0.30 \%$ o would produce $5-30 \%$ partial melts with $\delta^{30} \mathrm{Si}=-0.02$ to $-0.12 \%$ (Fig. 2, Supplementary Dataset 6 and Supplementary Text), consistent with the $\delta^{30} \mathrm{Si}$ values of modern adakites $\left(\delta^{30} \mathrm{Si}=-0.06 \pm 0.02 \%\right)$.

(2) Under a thermal gradient of $100^{\circ} \mathrm{Ckbar}^{-1}\left(\sim 33^{\circ} \mathrm{C} \mathrm{km}^{-1}\right)$, partial melting occurs at pressures $<8-10 \mathrm{kbar}$, in the presence of residual clinopyroxene, plagioclase and hornblende ${ }^{7,24}$ (Fig. 1). In contrast to adakites, felsic melts produced at these, relatively low, pressures would have higher concentrations of $\mathrm{Y}, \mathrm{Yb}, \mathrm{Nb}$ and $\mathrm{Ta}$, and negative $\mathrm{Sr}$ anomalies, as documented for Phanerozoic granites (Fig. 2, Supplementary Fig. 2 and Supplementary Dataset 3). The plagioclase-rich nature of the melting residues under this thermal gradient decreases $\Delta^{30} \mathrm{Si}_{\text {melt-residue }}$ to $\sim+0.17$ $0.21 \%$. Using the same basaltic source with $\mathrm{SiO}_{2}=50 \mathrm{wt} \%$ and $\delta^{30} \mathrm{Si}=-0.30 \%$, felsic melts derived from $5-30 \%$ partial melting at $850-900{ }^{\circ} \mathrm{C}$ would have $\delta^{30} \mathrm{Si}=-0.20$ to $-0.10 \%$ (Fig. 2, Supplementary Dataset 6 and Supplementary Text), which is consistent with the $\delta^{30} \mathrm{Si}$ values of Palaeozoic I- and A-type granites $\left(\delta^{30} \mathrm{Si}=-0.18 \pm 0.02 \%\right.$; Fig. 1$)$.

\section{Presence of sedimentary cherts in the sources of TTGs}

Depending on the modal fractions of plagioclase in the source, felsic rocks produced by melting under thermal gradients between 40 and $100^{\circ} \mathrm{Ckbar}^{-1}$ (that is, between 13 and $33^{\circ} \mathrm{Ckm}^{-1}$ ) should have $\delta^{30} \mathrm{Si}$ and $\mathrm{Sr} / \mathrm{Sr}^{*}$ values between those of adakites and granites (Fig. 2). Although Archaean TTGs have a range of chemical compositions encompassing those of adakites and granites, at identical $\mathrm{Sr} / \mathrm{Sr}^{*}$ values, TTGs have Si isotopic compositions shifted towards higher $\delta^{30} \mathrm{Si}$ values by +0.1 to $+0.2 \%$ o (except for one TTG sample, KV2.1/08; Fig. 2). The similarity of $\delta^{30} \mathrm{Si}$ values between Archaean komatiites and modern peridotites demonstrates the absence of a secular change in the Si isotopic composition of the Earth's mantle since $\sim 3.5$ billion years ago (Fig. 1). Therefore, the higher $\delta^{30} \mathrm{Si}$ values of Archaean TTGs relative to the Phanerozoic rocks generated at equivalent pressures require the presence of a component with a heavy $\mathrm{Si}$ in the source of TTGs. TTGs also have $\delta^{18} \mathrm{O}$ values that are $\sim 1 \%$ o higher than those of eclogite-derived felsic melts ${ }^{28-30}$, and the most likely explanation for these heavy-isotope enrichments for $\mathrm{O}$ and $\mathrm{Si}$ is the presence of a marine sedimentary chert component in the source of TTGs (Fig. 3). A similar interpretation has been previously proposed for the increased $\delta^{30} \mathrm{Si}$ values in some Phanerozoic andesites ${ }^{17}$, which, based on this study, can also be related to the addition of adakite-like slab melts.

\section{Significance for Si cycle and geodynamics of the Archaean}

Archaean marine sedimentary cherts have variable, but high $\delta^{30} \mathrm{Si}$ values between 0 and $+4 \% o$ (refs. ${ }^{31,32}$ ). They are derived from (1) precipitation of amorphous silica in oceans saturated with silica due to the lack of marine organisms that fix $\mathrm{Si}$ in their skeleton ${ }^{33}$, and (2) subsequent diagenetic reactions that form microquartz ${ }^{34}$. During the Archaean, silicic acid in the oceans acquired a high $\delta^{30} \mathrm{Si}$ value $^{31}$ due to the isotopic fractionations at depth in the oceanic crust between hydrothermal fluids (heavy $\mathrm{Si}$ isotope enrichment) and silicified basalts and gabbros (light $\mathrm{Si}$ isotope enrichment) $\left(\Delta^{30} \mathrm{Si}_{\text {precipitated silica-dissolved silicon }} \approx-1 \%\right.$ o (ref. $\left.\left.{ }^{35}\right)\right)$. Marine cherts are also enriched in ${ }^{18} \mathrm{O}$, due to the temperature-dependent oxygen isotopic fractionation between quartz and seawater (for example, $\Delta \Delta^{18} \mathrm{O}_{\text {quartz-seawater }}=+6 \%$ at $300^{\circ} \mathrm{C}$ to $=+31 \%$ at $25^{\circ} \mathrm{C}$ (ref. ${ }^{36}$; Fig. 3). Addition of $2.5-5.0 \%$ of sedimentary chert with $\delta^{30} \mathrm{Si}=+2 \%$ o and $\delta^{18} \mathrm{O}=+25 \%$ to a basaltic source with $\delta^{30} \mathrm{Si}=-0.30 \%$ and $\delta^{18} \mathrm{O}=+5.5 \%$ can account for the $\mathrm{O}$ and $\mathrm{Si}$ isotopic compositions of TTGs (Fig. 3 and Supplementary Fig. 4). Sedimentary chert is the most probable contaminant that can account for both the $\mathrm{O}$ and $\mathrm{Si}$ heavy-isotope enrichment of Archaean TTGs.

The evidence for contamination by sedimentary cherts implies that the basaltic source of TTGs had ample time for interacting with seawater, which precludes TTG formation by melting at the base of an oceanic plateau in a stagnant-lid regime. Oceanic subduction under moderate to high thermal gradients of $40-100^{\circ} \mathrm{C} \mathrm{kbar}^{-1}$, therefore, appears to be the most likely mechanism to bring this basaltic source in the appropriate pressure-temperature conditions for melting. Our data further suggest that only the top part (for example, the first few kilometres) of the subducted oceanic crust is likely to be melted. This is because the deeper parts of the oceanic crust are probably enriched in silica with low $\delta^{30} \mathrm{Si}$ values, since it precipitated from hydrothermal fluids with a $\delta^{30} \mathrm{Si}$ value around $-0.3 \%$ (ref. ${ }^{31}$ ), which is opposite to what is observed in TTGs 

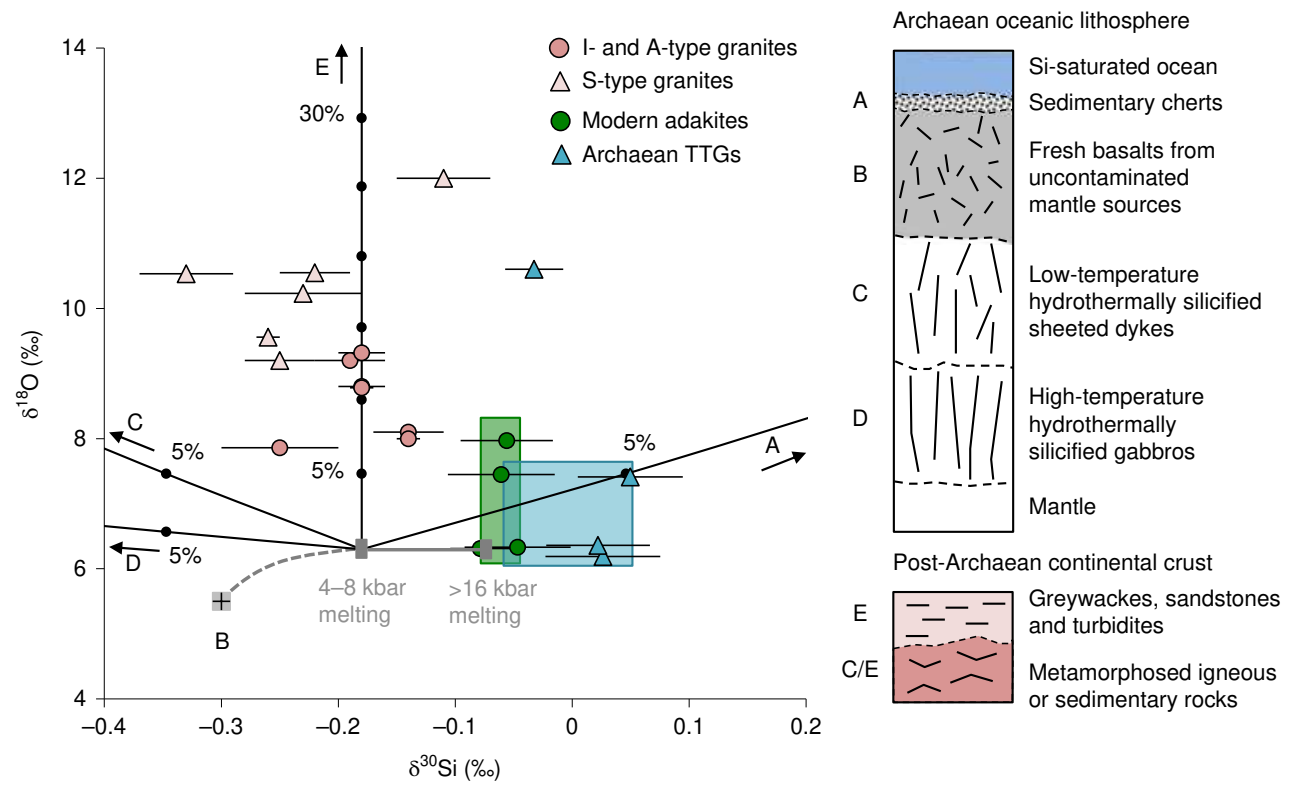

Fig. 3 Combining $\mathrm{O}$ and $\mathrm{Si}$ isotopes to trace hydrothermal or sedimentary addition. A indicates a sedimentary chert component selected from the chert dataset in ref. ${ }^{31}\left(\delta^{18} \mathrm{O}=+25 \%\right.$ and $\delta^{30} \mathrm{Si}=+2 \%$ ) , B indicates an uncontaminated basaltic source $\left(\delta^{18} \mathrm{O}=+5.5 \%\right.$ and $\delta^{30} \mathrm{Si}=-0.30 \%$ o $\left(\right.$ refs. $\left.\left.{ }^{18,19}\right)\right), \mathrm{C}$ indicates low-temperature hydrothermal silica ${ }^{42}\left(\delta^{18} \mathrm{O}=+25 \%\right.$ and $\delta^{30} \mathrm{Si}=-2 \%$ ) in silicified sheeted dykes, $\mathrm{D}$ indicates high-temperature silica ${ }^{42}\left(\delta^{18} \mathrm{O}=+10 \%\right.$ and $\delta^{30} \mathrm{Si}=-2 \%$ (ref. $\left.\left.{ }^{42}\right)\right)$ in silicified gabbros and $\mathrm{E}$ indicates greywackes, sandstones and turbidites in average $\left(\delta^{18} \mathrm{O}=+25 \% \circ\right.$ and $\delta^{30} \mathrm{Si}=-0.30 \% \circ\left(\right.$ ref. $\left.{ }^{12}\right)$ ). The $\delta^{18} \mathrm{O}$ and $\delta^{30} \mathrm{Si}$ values for partial melts from uncontaminated basalts at pressures of $4-8 \mathrm{kbar}\left(F=25 \% ; \delta^{18} \mathrm{O}=+6.3 \% \circ\right.$ and $\delta^{30} \mathrm{Si}=-0.18 \%$ ) and $>20 \mathrm{kbar}$ $\left(F=15 \% ; \delta^{18} \mathrm{O}=+6.3 \% \text { and } \delta^{30} \mathrm{Si}=-0.07 \% \text { o }\right)^{28}$, as well as those of felsic rocks in this study, and refs. ${ }^{12,41}$ are shown for comparison. Here $F$ indicates the degree of partial melting. The $\delta^{30} \mathrm{Si}$ values for the green and blue fields, respectively for adakites and TTGs, are from this study. The $\delta^{18} \mathrm{O}$ range for the adakite field includes the whole-rock $\delta^{18} \mathrm{O}$ values from ref. ${ }^{27}$ and those derived from olivines in ref. ${ }^{28}$, while the $\delta^{18} \mathrm{O}$ range of the TTG field is limited by the bulk $\delta^{18} \mathrm{O}$ values calculated from zircons in refs. ${ }^{29,30}$ (Supplementary Dataset 7). Note that the whole-rock $\delta^{18} \mathrm{O}$ values of Archaean TTGs can be altered by metamorphism, thus deviating from the TTG field defined by zircon values. Uncertainties on $\delta^{30} \mathrm{Si}$ are shown at the $95 \% \mathrm{Cl}$.

(Fig. 3). In the modern oceanic crust, the deeper plutonic rocks are indeed slightly lower in $\delta^{30} \mathrm{Si}$ compared with shallow lava flows ${ }^{37}$, and Archaean sedimentary cherts are 0 to $+4 \%$ o higher in $\delta^{30}$ Si than other Archaean uncontaminated ultramafic and mafic rocks ${ }^{12,17,31,32}$. The same conclusion holds for oxygen isotopes, since the bulk $\delta^{18} \mathrm{O}$ value of altered oceanic crust is close to that of fresh oceanic crust $^{38}$ $(+5.5 \% o)$, as observed in the Oman ophiolite ${ }^{39}$. For oxygen, this is due to the fact that the isotopic fractionation factor between water and carbonate (or silica) changes from being positive to being negative below the $\sim 300^{\circ} \mathrm{C}$ isotherm ${ }^{39}$. Partial melting of the top basaltic and chert layers of the subducted crust seems to be in line with the expectations from petrological considerations, as evidenced by experimentally determined phase relations ${ }^{40}$ in the nepheline-diopside-silica ternary diagram. Although silica itself is refractory, adding silica to basalts (5-20 wt\%, depending on basalt type) can reduce the solidus temperatures by $65-120^{\circ} \mathrm{C}$ (ref. ${ }^{40}$; Supplementary Fig. 5 , Supplementary Dataset 4 and Supplementary Information). Thus, in addition to the presence of high thermal gradients in the Archaean, the fact that the subducted basaltic crust could contain significant amounts of cherts would also have promoted its partial melting. It is noteworthy that a higher contribution of the upper high- $\delta^{18} \mathrm{O}$ layers of the subducted slab compared with the deeper low- $\delta^{18} \mathrm{O}$ layers has also been proposed for the origin of modern adakites ${ }^{28}$. The exact mechanism to melt refractory cherts and underlying mafic crust remains to be elucidated, but we speculate that melting could start at the interface between chert and basalt. Future experimental studies are necessary to further investigate this aspect. Overall, the evidence for incorporation of sedimentary cherts within magma sources of Archaean TTGs indicates that lateral motion of lithosphere (horizontal tectonics) and downward transport of sediments must have been operating, at least locally, since as early as $\sim 4.0$ billion years ago. We argue that oceanic subduction settings involving high thermal gradients were most likely responsible for the build-up of felsic continents in the Archaean.

\section{Online content}

Any methods, additional references, Nature Research reporting summaries, source data, statements of code and data availability and associated accession codes are available at https://doi.org/10.1038/ s41561-019-0407-6.

Published online: 26 August 2019

\section{References}

1. Martin, H. Adakitic magmas: modern analogues of Archaean granitoids. Lithos 46, 411-429 (1999).

2. Syracuse, E. M., van Keken, P. E. \& Abers, G. A. The global range of subduction zone thermal models. Phys. Earth Planet. 183, 73-90 (2010).

3. Martin, H. Effect of steeper Archean geothermal gradient on geochemistry of subduction-zone magmas. Geology 14, 753-756 (1986).

4. Foley, S. F., Buhre, S. \& Jacob, D. E. Evolution of the Archean crust by delamination and shallow subduction. Nature $\mathbf{4 2 1}$, 249-252 (2003).

5. Hopkins, M., Harrison, T. M. \& Manning, C. E. Low heat fl w inferred from $>4$ Gyr zircons suggests Hadean plate boundary interactions. Nature 456, 493-496 (2008).

6. Zegers, T. E. \& van Keken, P. E. Middle Archean continent formation by crustal delamination. Geology 29, 1083-1086 (2001).

7. Johnson, T. E. et al. Earth's fi st stable continents did not form by subduction. Nature 543, 239-242 (2017).

8. Moyen, J.-F. The composite Archaean grey gneisses: petrological signifi ance, and evidence for a non-unique tectonic setting for Archaean crustal growth. Lithos 123, 21-36 (2011). 
9. Guitreau, M., Blichert-Toft, J., Martin, H., Mojzsis, S. J. \& Albarède, F Hafnium isotope evidence from Archean granitic rocks for deep-mantle origin of continental crust. Earth Planet. Sci. Lett. 337, 211-223 (2012).

10. Palin, R. M., White, R. W. \& Green, E. C. R. Partial melting of metabasic rocks and the generation of tonalitic-trondhjemitic-granodioritic (TTG) crust in the Archaean: constraints from phase equilibrium modelling. Precambrian Res. 287, 73-90 (2016).

11. Trail, D. et al. Origin and signifi ance of $\mathrm{Si}$ and $\mathrm{O}$ isotope heterogeneities in Phanerozoic, Archean, and Hadean zircon. Proc. Natl Acad. Sci. USA 115 10287-10292 (2018).

12. Savage, P. S. et al. The silicon isotope composition of granites. Geochim. Cosmochim. Acta 92, 184-202 (2012)

13. Arndt, N. et al. Were komatiites wet? Geology 26, 739-742 (1998)

14. André, L., Abraham, K., Foley, S. F. \& Hofmann, A. Heavy $\delta^{30} \mathrm{Si}$ in Archean granitoids as evidence for supracrustal components in their sources. Goldschmidt 2018 abstr. 64 (2018); https://goldschmidtabstracts.info/2018/64.pdf

15. Méheut, M. \& Schauble, E. A. Silicon isotope fractionation in silicate minerals: insights from fi st-principles models of phyllosilicates, albite and pyrope. Geochim. Cosmochim. Acta 134, 137-154 (2014).

16. Qin, T., Wu, F., Wu, Z. \& Huang, F. First-principles calculations of equilibrium fractionation of $\mathrm{O}$ and $\mathrm{Si}$ isotopes in quartz, albite, anorthite, and zircon. Contrib. Mineral. Petrol. 171, 91 (2016).

17. Poitrasson, F. \& Zambardi, T. An Earth-Moon silicon isotope model to track silicic magma origins. Geochim. Cosmochim. Acta 167, 301-312 (2015).

18. Eiler, J. M. Oxygen isotope variations of basaltic lavas and upper mantle rocks. Rev. Mineral. Geochem. 43, 319-364 (2001).

19. Savage, P. S. et al. Silicon isotope homogeneity in the mantle. Earth Planet Sci. Lett. 295, 139-146 (2010).

20. Fitoussi, C., Bourdon, B., Kleine, T., Oberli, F. \& Reynolds, B. C. Si isotope systematics of meteorites and terrestrial peridotites: implications for $\mathrm{Mg} / \mathrm{Si}$ fractionation in the solar nebula and for Si in the Earth's core. Earth Planet. Sci. Lett. 287, 77-85 (2009).

21. Zambardi, T. et al. Silicon isotope variations in the inner Solar System: implications for planetary formation, differentiation and composition. Geochim. Cosmochim. Acta 121, 67-83 (2013).

22. Pringle, E. A. et al. Silicon isotopes reveal recycled altered oceanic crust in the mantle sources of oceanic island basalts. Geochim. Cosmochim. Acta 189, 282-295 (2016).

23. Savage, P. S. et al. Silicon isotope fractionation during magmatic differentiation. Geochim. Cosmochim. Acta 75, 6124-6139 (2011)

24. Rapp, R. P., Watson, E. B. \& Miller, C. F. Partial melting of amphibolite/ eclogite and the origin of Archean trondhjemites and tonalites. Precambrian Res. 51, 1-25 (1991)

25. McDonough, W. F. \& Sun, S. S. The composition of the Earth. Chem. Geol. 120, 223-253 (1995)

26. Defant, M. J. \& Drummond, M. S. Derivation of some modern arc magmas by melting of young subducted lithosphere. Nature 347, 662-665 (1990).

27. Stern, C. R. \& Kilian, R. Role of the subducted slab, mantle wedge and continental crust in the generation of adakites from the Andean Austral Volcanic Zone. Contrib. Mineral. Petrol. 123, 263-281 (1996).

28. Bindeman, I. N. et al. Oxygen isotope evidence for slab melting in modern and ancient subduction zones. Earth Planet. Sci. Lett. 235 , 480-496 (2005).

29. King, E. M., Valley, J. W., Davis, D. W. \& Edwards, G. R. Oxygen isotope ratios of Archean plutonic zircons from granite-greenstone belts of the Superior Province: indicator of magma source. Precambrian Res. 92 365-387 (1998).

30. King, E. M., Valley, J. W. \& Davis, D. W. Oxygen isotope evolution of volcanic rocks at the Sturgeon Lake volcanic complex, Ontario. Can. J. Earth Sci. 37, 39-50 (2000).

31. Robert, F. \& Chaussidon, M. A palaeotemperature curve for the Precambrian oceans based on silicon isotopes in cherts. Nature 443, 969-972 (2006).
32. Marin-Carbonne, J., Robert, F. \& Chaussidon, M. The silicon and oxygen isotope compositions of Precambrian cherts: a record of oceanic paleotemperatures? Precambrian Res. 247, 223-234 (2014).

33. Siever, R. The silica cycle in the Precambrian. Geochim. Cosmochim. Acta 56, 3265-3272 (1992).

34. Knauth, L. P. Petrogenesis of chert. Rev. Mineral. Geochem. 29, 233-258 (1994).

35. Ding, T. P. et al. Silicon Isotope Geochemistry (Geological Publishing House, 1996).

36. Knauth, L. P. \& Epstein, S. Hydrogen and oxygen isotope ratios in nodular and bedded cherts. Geochim. Cosmochim. Acta 40, 1095-1108 (1976).

37. Yu, H. M., Li, Y. H., Gao, Y. J., Huang, J. \& Huang, F. Silicon isotopic compositions of altered oceanic crust: Implications for $\mathrm{Si}$ isotope heterogeneity in the mantle. Chem. Geol. 479, 1-9 (2018).

38. Muehlenbachs, K. \& Clayton, R. N. Oxygen isotope composition of the oceanic crust and its bearing on seawater. J. Geophys. Res. 81, 4365-4369 (1976).

39. Gregory, R. T. \& Taylor, H. P. Jr An oxygen isotope profile in a section of Cretaceous oceanic crust, Samail ophiolite, Oman: evidence for $\delta^{18} \mathrm{O}$ buffering of the oceans by deep $(>5 \mathrm{~km})$ seawater-hydrothermal circulation at mid-ocean ridges. J. Geophys. Res. Solid Earth 86, 2737-2755 (1981).

40. Schairer, J. F. \& Yoder, H. S. Jr The nature of residual liquids from crystallization, with data on the system nepheline-diopside-silica. Am. J. Sci. A 258, 273-283 (1960).

41. Telus, M. et al. Iron, zinc, magnesium and uranium isotopic fractionation during continental crust differentiation: The tale from migmatites, granitoids, and pegmatites. Geochim. Cosmochim. Acta 97, 247-265 (2012).

42. Kleine, B. I. et al. Silicon and oxygen isotopes unravel quartz formation processes in the Icelandic crust. Geochem. Perspect. Lett. 7, 5-11 (2018).

\section{Acknowledgements}

We thank P. Louvat, T. Sontag and P. Burckel for help with the (multi-collector) inductively coupled plasma mass spectrometry. We thank G. Libourel for suggestions. I. Bindeman, M. Krawczynski, F. Poitrasson, E. J. Chin and M. Harrison are appreciated for their comments on an earlier version of this manuscript. I.S.P.s komatiite sample collection benefited from contributions of E. Nisbet, G. Byerly and C. Anhaeusser. We thank O. Sigmarsson for providing adakite samples. F.M. acknowledges funding from the ERC under the H2020 framework programme/ERC grant agreement no. 637503 (Pristine). F.M. and M.C. thank the financial support of the UnivEarthS Labex programme at Sorbonne Paris Cité (ANR-10-LABX-0023 and ANR-11-IDEX-0005-02). Parts of this work were supported by IPGP platform PARI, and by Region Île-de-France Sesame grant no. 12015908. M.G. acknowledges financial support from Région Auvergne (Auvergne Fellowship programme), LabEx ClerVolc (ANR-10-LABX-0006) and Agence National de la Recherche (ANR-17-CE31-0021 Zircontinents). This is ClerVolc contribution 353 .

\section{Author contribution}

Z.D., M.C., M.G. and F.M. designed the research project. M.G., I.S.P. and N.D. selected the TTGs/adakites, komatiites and granites, respectively, for study. Z.D. performed the research and analysed the data. Z.D., M.C., M.G., I.S.P., N.D. and F.M. contributed to interpreting the data and writing the paper.

\section{Competing interests}

The authors declare no competing interests.

\section{Additional information}

Supplementary information is available for this paper at https://doi.org/10.1038/ s41561-019-0407-6.

Reprints and permissions information is available at www.nature.com/reprints. Correspondence and requests for materials should be addressed to Z.D. Publisher's note: Springer Nature remains neutral with regard to jurisdictional claims in published maps and institutional affiliations. 


\section{Methods}

The TTG and granite samples were crushed and the quartz grains were handpicked under a microscope. Aliquots of the coarse-grained powders of the TTG samples $(\sim 1 \mathrm{~g}$ for each sample) were sieved in alcohol and crushed into fine powders using agate mortar and pestle. The selected quartz grains, as well as fine powders of TTGs, komatiites, adakites, NBS28 quartz and USGS GRM BHVO-2, were processed following the protocols described previously ${ }^{43}$. The sample powders (11-22 mg for quartz grains of granites and TTGs, $12-37 \mathrm{mg}$ for bulk komatities and adakites, and $44-86 \mathrm{mg}$ for bulk TTGs) were fused using $\mathrm{NaOH}$ as flux (10-15 times of the mass of the samples) in $\mathrm{Ag}$ crucibles at $720^{\circ} \mathrm{C}$ for $12 \mathrm{~min}$. The fusion cake was dissolved in $\mathrm{MQ}-\mathrm{e} \mathrm{H}_{2} \mathrm{O}(18.2 \Omega)$ and acidified with $1 \% \mathrm{HNO}_{3}$. Small aliquots of sample solutions were further diluted and measured on an Agilent quadrupole inductively coupled plasma mass spectrometer for Si concentrations and $\mathrm{Al} / \mathrm{Si}$ ratios, which were used to quantify the purity of the quartz grains from the TTG and granite samples. Solution aliquots containing $20 \mu \mathrm{g}$ Si from the samples were processed through BioRad Poly-Prep chromatography columns filled with 1.8 ml AG50X-12 (200-400 mesh) cation exchange resin to separate $\mathrm{Si}$ from the matrix. At low to neutral $\mathrm{pHs}$, dissolved $\mathrm{Si}$ is present as neutral or anionic species, which can be efficiently eluted by $\mathrm{H}_{2} \mathrm{O}$, while the cationic species are retained on the resin ${ }^{44}$. Sample solutions of $2 \mathrm{ppm} \mathrm{Si}$ in $0.2 \mathrm{M} \mathrm{HNO}_{3}$ were measured for their Si isotopic compositions on a Thermo-Fisher Neptune Plus multi-collector inductively coupled plasma mass spectrometer housed at the Institut de Physique de Globe de Paris using a quartz-made spray chamber. A medium resolution $(M / \Delta M \approx 5,000$, with $M$ the mass of the peak, and $\Delta M$ the mass difference between $5 \%$ and $95 \%$ relative peak heights) mode was used to avoid an isobaric interference from ${ }^{14} \mathrm{~N}^{16} \mathrm{O}^{+}$on mass ${ }^{30} \mathrm{Si}^{+}$. The alkali fusion solutions of NBS28 were processed through the same chemistry, and the purified solutions were run between samples to correct for instrumental mass bias. In every analytical session, the basalt reference material BHVO-2 was processed following the same procedure to monitor the accuracy of the analysis. Each measurement consisted of 25 cycles with an integration time of $8.389 \mathrm{~s}$. A two-step wash-out was performed after each measurement by rinsing with $0.5 \mathrm{M} \mathrm{HNO}_{3}$ and $0.2 \mathrm{M} \mathrm{HNO}_{3}$. The Si isotopic compositions of the samples are reported in Supplementary Dataset 1 using a per mil delta notation for ${ }^{30} \mathrm{Si} /{ }^{28} \mathrm{Si}$ or ${ }^{29} \mathrm{Si} /{ }^{28} \mathrm{Si}$ ratio relative to the $\mathrm{NBS} 28$ standard, that is, $\delta^{30} \mathrm{Si}$ or $\delta^{29} \mathrm{Si}$.

Two granites, four TTGs and four adakites measured for Si isotopes were also measured for whole-rock $\mathrm{O}$ isotopic composition by Activation Laboratories (Actlabs) following the procedures described in ref. ${ }^{45}$. The $\mathrm{O}$ isotopic results are reported in Supplmentary Dataset 8 using a per mil notation for the ${ }^{18} \mathrm{O} /{ }^{16} \mathrm{O}$ ratio relative to that of the Vienna standard mean ocean water (V-SMOW).

\section{Data availability}

The authors declare that the data supporting the findings of this study are available within the article and its supplementary information files (that is, the Supplementary Information and additional datasets).

\section{References}

43. Pringle, E. A., Moynier, F., Savage, P. S., Badro, J. \& Barrat, J. A. Silicon isotopes in angrites and volatile loss in planetesimals. Proc. Natl Acad. Sci USA. 111, 17029-17032 (2014).

44. Georg, R. B., Reynolds, B. C., Frank, M. \& Halliday, A. N. New sample preparation techniques for the determination of $\mathrm{Si}$ isotopic compositions using MC-ICPMS. Chem. Geol. 235, 95-104 (2006).

45. Clayton, R. N. \& Mayeda, T. K. The use of bromine pentafluoride in the extraction of oxygen from oxides and silicates for isotopic analysis. Geochim. Cosmochim. Acta 27, 43-52 (1963). 